\title{
Study the Effect of Different Lactation Stages on Minerals of Pantja Goat Milk
}

\author{
Surya Pratap Singh Chauhan*, Sanjay Kumar, Anjali Jeena, Rajat Verma, \\ Vijay Amrit Raj Panwar, Pankaj Patel and Mohit Budhalakoti
}

Department of Livestock Production Management, C.V.A.Sc. GBPUAT, Pantnagar-263145, Uttarakhand, India

*Corresponding author

\section{Keywords}

Pantja goat, Milk, Effect of lactation stage, Minerals

Article Info

Accepted:

12 May 2019

Available Online:

10 June 2019

\section{A B S T R A C T}

Goat is universally recognized as "Poor man's cow". It is a very versatile animal because of short generation interval, browsing habit, low investment, and high rate of prolificacy. Milk is the complete and first food of mammals which provides energy and nutrients needed for the proper growth and development. Goat milk is superior in nutrients and is having better digestibility, alkalinity, buffering capacity and certain therapeutic values. During the entire study the fresh milk samples of Pantja goats according to stage of lactation were analyzed for minerals content. The statistical analysis of the data indicated that the stage of lactation has effect on the minerals content in Pantja goat milk. In the present investigation, calcium level was increased in early lactation followed by the mid and late stage of lactation and also phosphorus level increased in early stage lactation but followed by a late and mid-stage of lactation. Magnesium, Potassium, Sodium level were increased in the late stage of lactation followed by the mid and early stage of lactation. Trace minerals selenium, zinc, iron, and manganese increased in the early stage of lactation followed by the mid and late stage of lactation.

\section{Introduction}

Goat is considered as an animal with multipurpose utility which not only provides meat and milk but also hide, hair and manure. It is a well-known fact that goat industry has provided significant improvement to the native economy (FAO, 2010). Goat milk has assumed a significant job in the nourishment and financial prosperity of mankind by giving every day basic proteins and minerals, for example, calcium and phosphate (Haenlein,
1980). Goat milk has been prescribed as a perfect alternative for cow milk, particularly for the individuals who experience the ill effects of bovine milk hypersensitivity (Park and Haenlein, 2007). Goat milk has higher medicinal value than any other milk and it also contains 4.4 percent fats, 0.137 percent Calcium, 0.112 percent Phosphorus, 0.017 percent Magnesium, 0.170 percent potassium and 3.4 percent milk protein (Holmes et al., 1946). On average, goat and cow milk provides approximately 72 and $67 \mathrm{Kcal}$ of 
energy per $100 \mathrm{~g}$ respectively. It is almost naturally homogenized because of smaller sizes of fat globules. Large portion of human community in the world is malnourished because of lack of protein, energy along with minerals and vitamins. Goat's milk can overcome these problems by providing better nutrition. Hence this can give support to human starvation, under nutrition, and malnutrition in the world's lower strata peoples. Goat milk has superior digestibility and an appropriate composition of fatty acids and bioactive compounds which is useful in managing certain medical conditions. The main quality of milk is to supplement nitrogen and amino acids to the young mammals. Milk is considered as an essential portion of dietary fat requirements in adults. Furthermore, milk fat facilitates the uptake of several vital nutrients such as trace elements, vitamins, minerals and performs a defensive function (Brule et al., 1982).

The nutritional and health prosperity of goat milk are important to be noted because it avoids various medical complications of people like food hypersensitivity due to cow milk (Walker, 1965). The vitamin A content in goat milk is more than that in cow milk as in goat's milk conversion of all $\beta$-carotene into Vitamin A occurs. Goat milk is whiter than the cow milk. Sufficient amount of vitamin A and niacin is supplemented through goat milk and even high amounts of thiamin, riboflavin and pantothenic acid for human infants is supplemented (Parkash and Jenness, 1968). Dengue has become a major health problem in India. For treating dengue fever goat milk and its milk products are mostly preferred. Dengue fever has complications like deficiency of selenium and reduced platelet count. Goat milk and its products are enriched with more selenium as compared to cow milk. Goat milk also aid in the digestive and metabolic utilization of various minerals (Gunjan et al., 2011).

\section{Materials and Methods}

\section{Sampling}

For the current investigation 27 Pantja goats were selected from the Department of Livestock Production Management, College of Veterinary and Animal Sciences, G.B.Pant University of Agriculture and Technology, Pantnagar. These goats were classified into three groups as per their lactation stages which are as below:

Lactation stage first $\left(\mathrm{S}_{1}\right)$ (Up to 30 days) Lactation stage second $\left(S_{2}\right)$ (31 to 60 days) Lactation stage third $\left(\mathrm{S}_{3}\right)$ (above 61 days)

During the entire study, the fresh milk samples were collected from the Pantja goats. The milk samples were taken early in the morning from the goats being reared in the Department of Livestock Production Management. During this period, individual goats were milked and after that samples were collected and labeled in $50 \mathrm{ml}$ sterile bottles and brought to the laboratory for further analysis. The collected samples were preserved in a refrigerator at $5^{\circ} \mathrm{C}$ until they were investigated.

\section{Sample preparation}

Determination of minerals includes digestion of milk sample which was done by adding50 $\mathrm{ml}$ of $24 \%$ TCA to $5 \mathrm{ml}$ of each milk sample in a volumetric flask. The samples were mixed at 5-6 minutes interval for 30 minutes, and then each sample was centrifuged at 4000 rpm for 5 minutes. Then each sample was filtered using filter paper and filtrate was collected in the Stoppard bottle for further Atomic Absorption analysis. For running the samples on Atomic absorption, different parameters were maintained like Pressure and Temperature. The temperature was fixed at the range of $2500{ }^{\circ} \mathrm{C}$ and Pressure of air at the 
range of 6Psi and the Pressure of Acetylene is 2Psi. After the fixation of parameters, standards of various ppm (parts per million) for each sample were used first. After the standards, different digested samples of different ranges were used for the analysis of the various minerals. Each sample gave a different concentration of minerals one by one serially in $\mu \mathrm{g} / \mathrm{ml}$.

\section{Results and Discussion}

\section{Calcium}

The statistical analysis of the data indicated that the stage of lactation has show effect on the calcium content in milk. In the present investigation, the overall calcium content of Pantja goat milk was $893.06 \mathrm{mg} / \mathrm{L}$. The calcium content of milk was affected by stage of lactation. The average values of calcium content in the early, mid and late stage of lactation was 902.85, 891.34 and 885.56 which showed more in the early lactation stage followed by the mid and late lactation stage.

\section{Magnesium}

The statistical analysis of the data indicated that the stage of lactation has show effect on the magnesium content in milk. In the present investigation, the overall magnesium content of Pantja goat milk was $114.78 \mathrm{mg} / \mathrm{L}$. The magnesium content of milk was affected by stage of lactation. The average values of magnesium content in early, mid and late lactation stage was 13.08, 15.09 and 16.04 which showed more in late lactation stage followed by the mid and early lactation stage.

\section{Phosphorus}

The statistical analysis of the data indicated that the stage of lactation has show effect on the phosphorus content in milk. In the present investigation, the overall calcium content of Pantja goat milk was $1122.26 \mathrm{mg} / \mathrm{L}$. The phosphorus content of milk was affected by stage of lactation. The average values of phosphorus content in early, mid and late stage of lactation was 1125.23, 1118.40 and 1121.69 which showed highest in the early stage of lactation followed by a late and midstage of lactation.

\section{Potassium}

The statistical analysis of the data indicated that the stage of lactation has show effect on the potassium content in milk. In the present investigation, the overall potassium content of Pantja goat milk was $1168.49 \mathrm{mg} / \mathrm{L}$. The potassium content of milk was affected by stage of lactation. The average values of potassium content in early, mid and late stage of lactation was $1165.95,1168.90$ and 1170.73 which showed highest in the late stage of lactation followed by the mid and early stage of lactation.

\section{Sodium}

The statistical analysis of the data indicated that the stage of lactation has show effect on the sodium content in milk. In the present investigation, the overall sodium content of Pantja goat milk was $635.41 \mathrm{mg} / \mathrm{L}$. The sodium content of milk was affected by stage of lactation. The average values of sodium content in the early, mid and late stage of lactation was 633.83, 634.81 and 637.61 which showed highest in the late stage of lactation followed by the mid and early stage of lactation.

\section{Manganese}

The overall mean of manganese content in Pantja goat milk was $0.037 \mathrm{mg} / \mathrm{L}$. Stage of lactation had effected on manganese content in milk. Stage of lactation wise averages of 
manganese content in Pantja goat milk was $0.147,0.137$ and $0.129 \mathrm{mg} / \mathrm{L}$. in early, mid and late lactation, respectively and more in the early lactation stage followed by the mid and late lactation stage.

\section{Zinc}

The overall mean of zinc content in Pantja goat milk was $2.36 \mathrm{mg} / \mathrm{L}$. It was noticed that the stage of lactation had effected on zinc content in milk. The average zinc content in Pantja goat milk was increased from late lactation to early lactation and average value of zinc 2.38, 2.36 and $2.34 \mathrm{mg} / \mathrm{L}$ in early, mid and late lactation stage, respectively.

\section{Selenium}

The statistical analysis of the data indicated that the stage of lactation has show effect on the selenium content in milk. In the present investigation, the overall selenium content of Pantja goat milk was $0.013 \mathrm{mg} / \mathrm{L}$. The selenium content of milk was affected by stage of lactation. The average values of selenium content in early, mid and late stage of lactation was $0.0142,0.0139$ and 0.0138 which showed more in the early lactation stage followed by the mid and late lactation stage.

\section{Iron}

The statistical analysis of the data indicated that the stage of lactation has show effect on the Iron content in milk. In the present investigation, the overall Iron content of Pantja goat milk was $0.50 \mathrm{mg} / \mathrm{L}$.

The Iron content of milk was affected by stage of lactation. The average values of iron content in early, mid and late stage of lactation was $0.60,0.55$ and 0.35 which showed more in the early lactation stage followed by mid and late lactation of stage.
The statistical analysis of the data indicated that the stage of lactation has show effect on the minerals content in Pantja goat milk. In the present investigation, calcium level was increased in early lactation followed by the mid and late stage of lactation and phosphorus level also increased in early stage lactation but followed by a late and mid-stage of lactation. Magnesium, potassium, sodium level was increased in the late stage of lactation followed by the mid and early stage of lactation. Trace minerals selenium, zinc, iron, and manganese increased in the early stage of lactation followed by the mid and late stage of lactation.

\section{References}

AOAC, 2005. Official methods of Analysis, $17^{\text {th }}$ edition. Association of Official Analytical Chemists, Washington, DC, USA.

Brule, G., Roger, L., Fauquant, J. and Piot, M. 1982. Phosphopeptides from casein derived material. U.S. Patent, 4: 358465.

FAO. 2010. Food and agriculture organization. Production yearbook, Rome, Italy.

Gunjan, M., Sharma, P.K., Garg, V.K., Singh, A.K. and Mondal, S.C., 2011. Role of Goat Milk and Milk Products in Dengue Fever. J. Pharmaceu. and Biomed. Sci., 8(6): $1-5$.

Haenlein, G.F.W. 1980. Mineral nutrition of goats. J. Dairy Sci., 6(3): 1729-1748.

Holmes, A.O., Kuzmeski, J.W., Lindquist, H.G. and Rodman, H.B. 1946. Goat milk as a source of bone building minerals for infant feeding. Dairy Sci. 8(34): 194-196.

ISI, 1960. IS: 1479 (Part-1) Indian Standard Institution, Manak Bhawan-9, Bahadur Shah Zafar Marg, New Delhi.

ISI, 1961. IS: 1479 (Part-2) Indian Standard Institution, Manak Bhawan-9, Bahadur 
Shah Zafar Marg, New Delhi.

ISI, 1965. IS: 1183, Indian Standard Institution, ManakBhawan, BahadurShahZafarMarg, New Delhi.

ISI, 1977. IS: 1224 (Part-2) Indian Standard Institution, Manak Bhawan-9, Bahadur Shah Zafar Marg, New Delhi.

Park, Y.W., Juárez, M., Ramos, M. and Haenlein, G.F.W. 2007. Physicochemical characteristics of goat and sheep milk. Small Rumin. Res., 68(3): $88-113$.

Parkash, S. and Jenness, R. 1968. The composition and characteristics of goat's milk: A review. In Dairy Sci. Abstr., 30(2): 67-87.

Walker, V.B. 1965. Therapeutic uses of goat's milk in modern medicine. British Goat Society's Yearbook, 66(4): 26-29.

\section{How to cite this article:}

Surya Pratap Singh Chauhan, Sanjay Kumar, Anjali Jeena, Rajat Verma, Vijay Amrit Raj Panwar, Pankaj Patel and Mohit Budhalakoti. 2019. Study the Effect of Different Lactation Stages on Minerals of Pantja Goat Milk. Int.J.Curr.Microbiol.App.Sci. 8(06): 1598-1602. doi: https://doi.org/10.20546/ijcmas.2019.806.192 